\title{
The Hidden Curriculum of Monolingualism: Understanding Metonymy to Interrogate Problematic Representations of Raciolinguistic Identities in Schoolscapes
}

\author{
Steve Daniel Przymus \\ Texas Christian University \\ U. S. A. \\ Gabriel Huddleston \\ Texas Christian University \\ U. S. A.
}

\begin{abstract}
Choices regarding how signs are displayed in schools send messages regarding the status of languages and speakers of those languages. The monolingual paradigm can be implicitly reified by the position, shape, color, etc. of languages in relation to English on school signage (Przymus \& Kohler, 2018). This can have a negative impact for culturally and linguistically diverse youth. In combining bilingual/multicultural education with linguistic landscape research, we uncover a hidden curriculum of raciolinguistic ideologies (Alim, 2016), and confront the hegemony found on some of the most overlooked and under questioned representations of curriculum - signs in schools.
\end{abstract}

KEYWORDS: linguistic landscapes, metonymy, raciolinguistics, schoolscape

\author{
Objectives \\ Situating Main Concepts in the Literature \\ Methodology \\ A Heteroglossic Way Forward \\ Conclusion \\ Notes \\ References \\ Author Contact
}

We landscape.

We select, focus, and develop, bringing more clearly and vibrantly into view particular features that we frame and foreground, while simultaneously disregarding or minimizing other features and dimensions that we might have selected, developed, and showcased instead (Royster, 2003, p. 148). 
While all languages are potentially equal, they are, for social reasons, not actually so (Hymes, 1992). This paper takes an interdisciplinary approach through bridging cognitive linguistics, linguistic landscape research, and bilingual education to provide a unique lens of analysis for suggesting that some forms of curriculum have been forgotten, normalized, and naturalized in multicultural education, and therefore have stopped being critically analyzed. In recent years it has become common for teacher educators and educational stakeholders to place multicultural education "under the guise of 'global education'...this form of multiculturalism feels safer to some because it uses the veneer of international cultures to avoid more serious and painful realities of issues like racism" (Au, 2014, p. 1). This problematic reverse indexicality of international cultures (Przymus, 2017 ) is the focus of our study. What we take up here are bilingual signs in schoolscapes that reify the myth that, when used simultaneously, languages (and by default the speakers of those languages) are somehow equal. This is a dangerous practice and a hidden curriculum that requires engagement and critical analysis.

We find Royster's (2003) above metaphor of "landscaping" helpful for bridging work in multicultural education, bilingual education, cognitive linguistics, and linguistic landscapes, because it provides a fertile image of how space is organized through curriculum and what kinds of linguistic messages (both explicit and implicit) are co-created between students, parents, educators, etc. and the signs they passively interact with at schools. This metaphor of landscaping provides a mechanism for examining and understanding that what we currently know about multicultural education

is situated on a larger terrain of developed and undeveloped possibilities...the imperative is to recognize that the process of showcasing space is an interpretative one, one that acknowledges a view and often rescopes that view in light of aesthetic sensibilities - values, preferences, beliefs (Royster, 2003, p. 143).

There are multiple perspectives regarding the influence language in the classroom has on human thought and action. Is the classroom a "microcosm of the social order" or does the classroom environment provide a setting to problematize and contest reality, "related to broader social and political domains" (Pennycook, 2010 , p. 116)? Both of the above perspectives on the influence of language at school, although on different ends of the continuum, are similar in that they both privilege humans as the locus of control and agency. There is a sense in both of these perspectives that language, in and of itself, apart from the speaker and interlocutor, has agency; but, language is still traditionally linked to humans. What we propose is that in order to confront and interrogate the hidden curriculum of signs in schools, we must first be aware of the agency and influence of signs, and how this influence is implicitly enacted via the cognitive phenomenon of conceptual metonymy. Within, we describe how the "thing power" (Bennett, 2010) and agency of signs are hidden curriculum, implicitly understood through conceptual metonymy or a cognitive process that creates "natural inference schemas" and implicit construction of meaning (Panther \& Thornburg, 2005, p. 353). In this paper, 
we call for an awakening regarding the agency of things in schoolscapes (Brown, 2012) and present an entanglement of reality, where matter and the agency of matter is entangled with human discourse, through conceptual metonymy. Barthes (1967) wrote of this entanglement of things and people, regarding clothing, pasta, wine, professional wresting, etc., and pointed out that "as soon as there is a society, every usage is converted into a sign of itself" (Barthes, 1967, p. 41).

\section{Objectives}

An unintentional consequence of historical experiences and institutional curriculum, not publicly acknowledged yet perceived by students, educators, and parents, is a hidden curriculum (Martin, 1976; Wang, 2020). The meanings, the myths, the truths produced by, with, and between a student, parent, teacher, and the signs that they interact with at schools cannot be assumed and normed and therefore must be questioned and critiqued. What we provide here is a possible cognitive insight into how signs, even in settings where bilingualism is championed, produce messages that reify the monolingual paradigm that privileges English and English speakers over other languages and speakers of other languages, and acts to recreate within the school walls the unequal social order beyond the walls. Understanding and leveraging the implicit power of metonymy in language use at schools is imperative for moving towards revolutionary classrooms that contest and work to change social and political domains.

Daily choices regarding how signs are displayed in and around bilingual education settings are important and send meaningful messages regarding the status of languages and, by default, the status of speakers of those languages. The monolingual paradigm, a largely unconscious ideology that privileges English over other languages in the U.S., can be implicitly reified daily by the position, shape, color, etc. of languages in relation to English on school signage (Phillipson, 1992; Przymus, 2016). In this paper, we demonstrate how the language in the linguistic landscape of schools or schoolscapes can implicitly act to undermine the equality of bilingual education and reinforce adverse perceptions and ideologies of Spanish and other languages.

Critique of linguistic landscape research has pointed to the difficulty in proving any convincing relationship between messages in our environment and human thought (Przymus \& Kohler, 2018). "If we claim that it is through semiotic activity that physical space is turned into social, cultural and political space, we need to understand how exactly these processes of semiotization operate" (Blommaert, 2013, p. 14). To address this critique, we apply the Semiotic Index of Gains in Nature \& Society (SIGNS) framework (Przymus \& Kohler, 2018) in order to present a holistic semiotic analysis of the hidden curriculum of monolingualism in U.S. bilingual schoolscapes. The SIGNS framework (see Image 1 below) is an eight-point critical semiotic analysis that, when applied to the linguistic landscape of a context, allows semioticians to analyze (1) the diachronic (across periods of time in the past) meaning of signs/media; (2) the synchronic (present day) meaning of signs/media; (3) the myths promulgated throughout history and in present day; 
(4) the conceptual metaphors that are both produced and are products of signs/media; (5) the conceptual metonymy underlying the production and meaning of the signs/media, including how signs/media can be understood subconsciously, and therefore not questioned, on the (6) syntagmatic and (7) paradigmatic axes; and finally how signs/media in our linguistic landscape can be analyzed, interpreted, and understood as (8) either elective or circumstantial reverse indexicality.

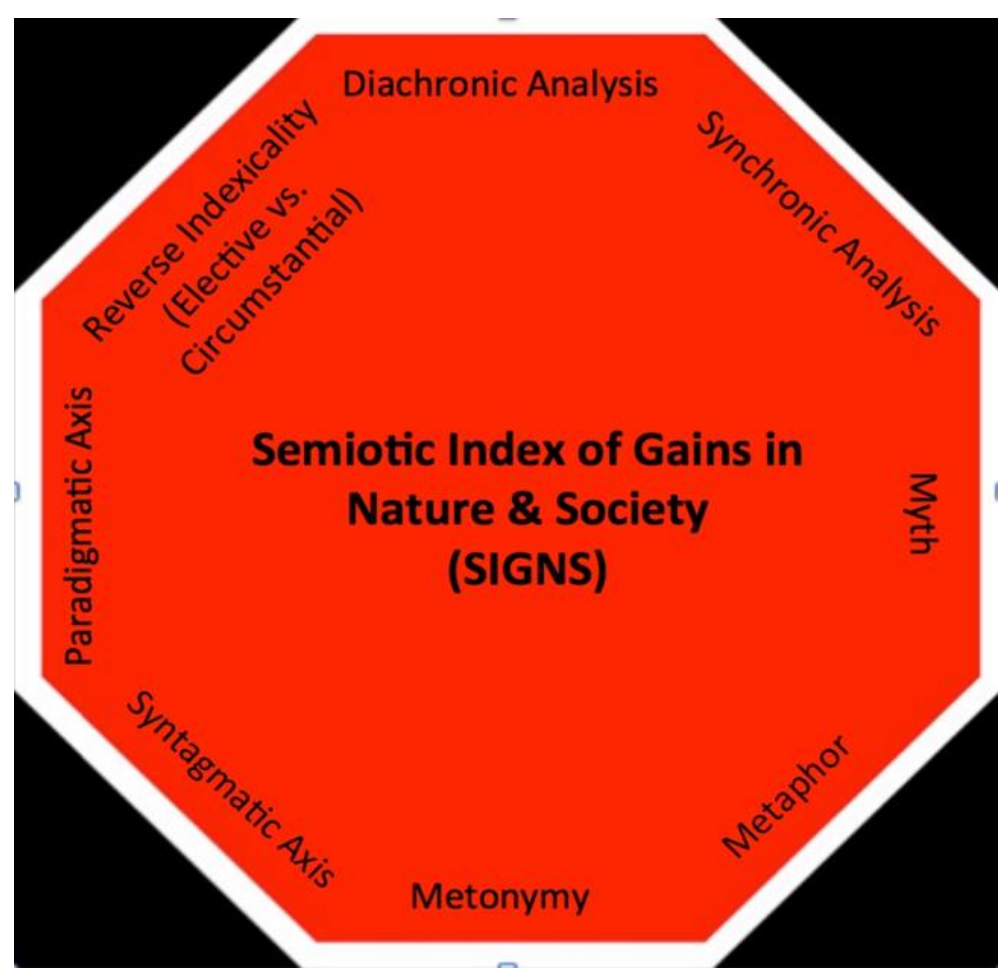

Image 1. The Eight Points of Analysis of the SIGNS Framework

Towards the end of the paper, in the Future Directions: A Heteroglossic Way Forward section, we will briefly provide how each of these eight points of semiotic analysis could be applied with students to interrogate the hidden curriculum of monolingualism and raciolinguistic ideologies in schoolscapes; but, for purposes of space and to provide a very specific and practical opportunity to make an immediate positive impact on multicultural education, we will focus the bulk of this paper on only the $5^{\text {th }}$ point of critical semiotic analysis - conceptual metonymy.

Through introducing two new metonymies, Directional Metonymy (GOOD IS UP, BAD IS DOWN, FIRST IS BEST, etc.) and Font Style Metonymy (FONT SIZE/COLOR/TYPE FOR IMPORTANCE), we demonstrate how signs in and around schools implicitly create diglossic dichotomies of big vs small languages, important vs less important languages, normal vs abnormal, official vs unofficial, legal vs illegal, etc. and thus metonymically create these same categories for the speakers of these languages (Przymus \& Kohler, 2018). This positioning of identities through unconscious use of signage in and around schools goes largely 
unnoticed, but can have a great impact on expectations both placed on culturally and linguistically diverse youth at schools and on the expectations that these students have for themselves. In explicitly addressing the implicit power of language, we uncover hidden raciolinguistic ideologies or "the relations between language, race, and power" (Alim, 2016, p. 3), and in doing so, we contribute to the work on addressing disparate educational opportunities and work to improve equitable educational and life realities.

\section{Situating Main Concepts in the Literature}

In order to bridge multicultural education, cognitive linguistics, bilingual education, and linguistic landscapes, below we situate this study in the literature of these disciplines and draw connections between our interdisciplinary approach and previous work in the literature on critical multimodal discourse analysis. Through a critical multimodal discourse analysis of the linguistic landscapes/schoolscapes of bilingual, multicultural schools, we ask: What hidden curriculum of monolingualism is present in schools, promulgating normalized/unquestioned messages that are in direct quotidian interaction with students, educators, school leaders, and parents upon entering schools? How are these implicit/metonymic messages conveyed in a unidirectional, static, diglossic organization and how can these messages be contested with a more heteroglossic/translanguaging approach, that allows for multidirectional, diverse, and organic representations of languages/cultures?

Scholars in linguistic landscape (LL) (Landry \& Bourhis, 1997) and, more recently, schoolscape research (Brown, 2012) have taken up the charge of investigating and explaining the diachronic and synchronic implicit messages, hidden intentions, agendas, and ideologies embedded in our daily surroundings (Przymus \& Kohler, 2018). In this paper, we continue this work to expose the metonymy of monolingualism in bilingual and multicultural schoolscapes. Due to the diagrammatic iconicity (Nöth, 2008; Peirce, 1904; Waugh, 1994) of school hallways and classroom signage, we argue that these signs are both some of the most influential and unquestioned influences in schoolscapes and that their organization, composition, and ideological messages of monolingualism demand critique. The diagrammatic iconicity of signs, however, can become routine and "lull us into a passive interaction with them that lays the fertile soil for an environment of false consciousness" (Przymus, 2017, p. 9). This false consciousness can become, then, the new truth about languages and the status of speakers of different languages in schools - especially in schools with bilingual education programs.

\section{Why Bilingual Education as the Context of Analysis}

Bilingual education policy in the U.S. has never had the objective of bilingualization; instead, it has been designed to teach English to speakers of languages other than English, preferably by replacement rather than addition (Richard Ruiz, personal communication, August 29, 2013). "Language can serve, in all spheres of social life, to bring people together or to divide them" (Kontra et 
al., 1999, p. 1). Where this social, political, and ideological division largely goes unquestioned and hidden is in educational contexts where bilingualism is heralded; even where languages are promoted as being equal, an "other" is created. This context is too often not questioned as a battlefield of language ideologies and, rather, is considered a green zone for language diversity and respect. Contexts of bilingual education, however, are some of the most influential and important contexts of language othering, language erasure, and the maintenance of English hegemony in U.S. schools. This is one effect of the monolingual paradigm.

\section{The Monolingual Paradigm}

The initial response to many reading this paper may be that simply using both languages on signs is an explicit attempt to make both languages equal. Historically, this has been the same argument for rigid policies of language separation in bilingual education contexts. The argument goes that both languages need to be used, represented, and in equal proportions or English, the dominant language in society, will be privileged and used more, at the expense of the other language of the bilingual program. However convincing this argument is and continues to be in many contexts, by default "separate" is always unequal. Separating languages on signs, in classroom instruction, and even in translating/interpreting exercises creates linguistic binaries, fronteras, dichotomies of big-little, good-bad, important-less important, etc., and diglossic contexts where one language always rises to the top. To date, this pedagogical practice of separating languages has been problematized greatly, including by Creese's and Blackledge's (2010) call to "challenge the monolingual macro order" (p. 104); García's (2007) discussion of "diglossic functional separation" (p. xiii); Heller's (1999) critique of "parallel monolingualism" (p. 271); Swain's (1983) commentary on "bilingualism through monolingualism" (p. 4); and the debunking of the "two monolinguals in one body" myth, underlying this separation of languages by Gravelle (1996, p. 11; see also Grosjean, 1989). Still, this practice remains. What has not been questioned is how languages are organized, separated, portrayed, positioned, and displayed together on signage at schools, especially in bilingual schools, where the simple use of both languages on one sign is seen as a good thing. Below, we specifically point to what goes unquestioned about signs: Their underlying conceptual messages, produced by the cognitive phenomenon that is metonymy.

\section{Monolingual Metonymy in Schoolscapes}

Our everyday language is awash with metonymy. When we talk about the White House, or the suits on Wall Street, argue about illegal immigrants or aliens, we produce metonymies (Przymus \& Kohler, 2018). Work in cognitive linguistics and multimodal critical discourse analysis has uncovered the implicit power of metonymy. Przymus \& Kohler (2018, p. 63) claim that

Metonymy functions, in essence, through a 'STANDS FOR' relationship (Catalano \& Waugh, 2013)...metonymy construction and reception represent and are engaged with our underlying conceptual mechanisms (Gibbs, 1994) that help us not only organize and make sense of the world 
around us, but in their production help us shape it, draw inferences about it, and reason our way through it. (Catalano \& Waugh, 2014)

\section{Two New Metonymies}

The STANDS FOR function of the above examples of metonymies have been written about in the literature and recognized as (PLACE FOR GOVERNMENT-the White House), (CLOTHING FOR PROFESSION-suits, also PLACE FOR PROFESSION-Wall Street), (DEFINING PROPERTY FOR PERSON-illegal immigrants), and (NON-PERSON FOR PERSON-aliens). What we propose in this current study is that other STANDS FOR relationships exist in the schoolscape of bilingual programs and have an effect on raciolinguistic ideologies and practices. We introduce to the literature, Directional Metonymy (GOOD IS UP, BAD IS DOWN, FIRST IS BEST, etc.) and Font Style Metonymy (FONT SIZE/COLOR/TYPE FOR IMPORTANCE), and point out the ubiquitous and hidden nature of these metonymies in schoolscapes. Image 2, below, exemplifies the Directional Metonymy category. By placing the English sign first, on the left, and above the Spanish sign, the implicit message is that English is more important. Adding to this, the Spanish sign has been partially covered-up by an English "WELCOME" sign in all caps, strengthening the message further that English is the language that needs to be seen first and fully, and really is the language that matters.

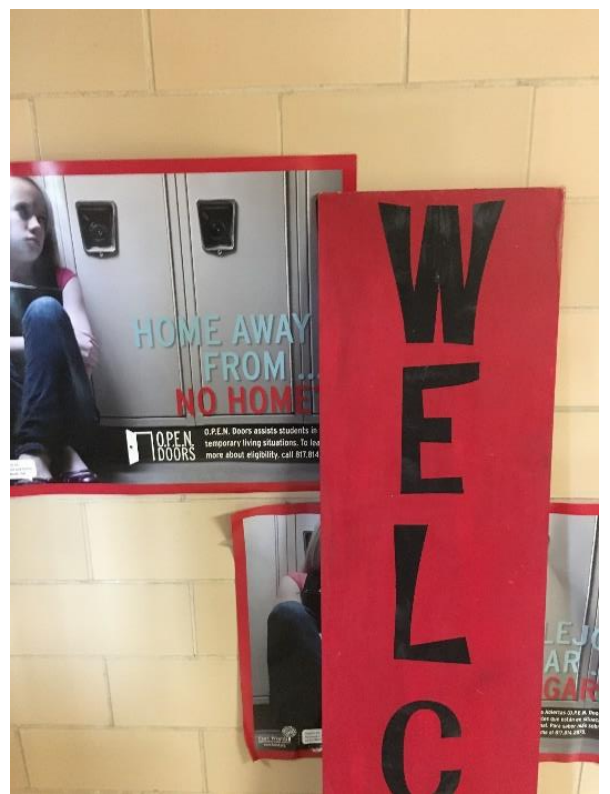

Image 2. Bilingual Signs inside the Entrance of School \#1

Image 3 contains examples of directional metonymy, as again the English writing and signs are both on the left and on top, but here we also see examples of font style metonymy, as the English words are bold, bigger, colorful, not in parentheses. In addition, the two languages are assigned specific colors (more on this below): English is blue and Spanish is red. Clearly, the metonymic message here is that English is the more valued language. 


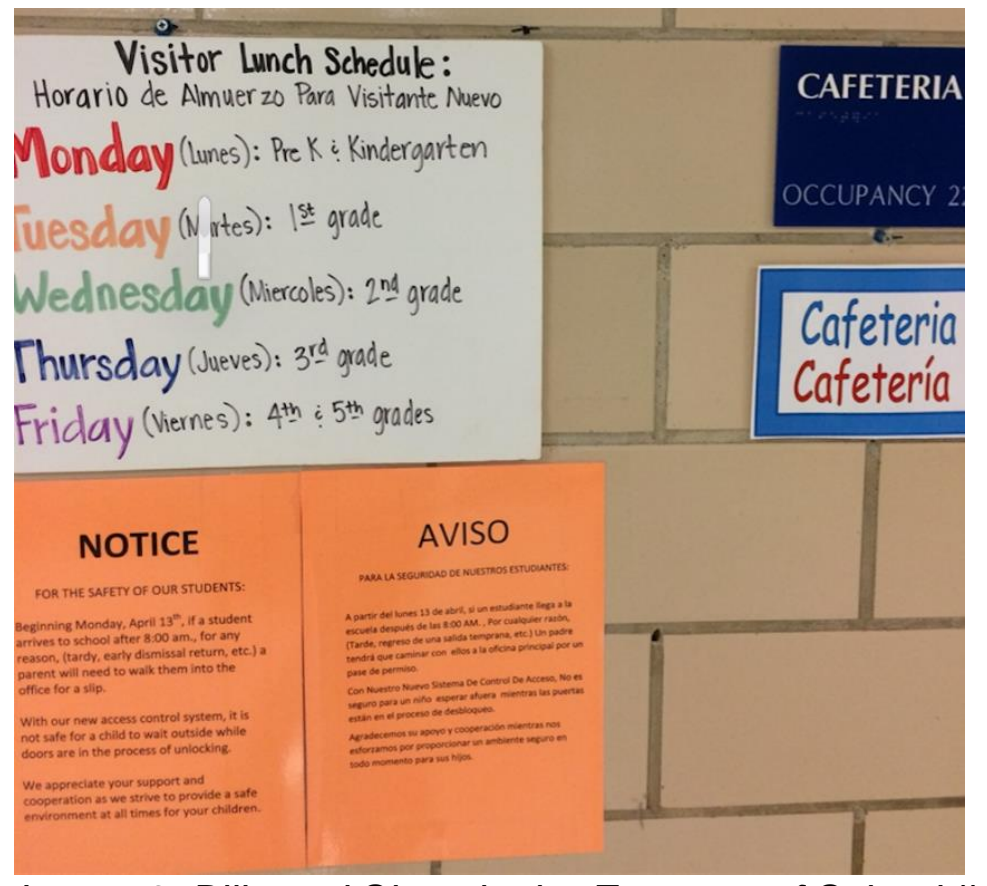

Image 3. Bilingual Signs in the Entrance of School \#1

The origin of assigning English (blue) and Spanish (red) a color comes from the widely adopted "Gomez \& Gomez" dual-language model, which stipulates that all English signs in classrooms be in blue font and all Spanish in red font (Gomez et al., 2005). These are not meaningless color assignations. Blue has been found to be "the most preferred color in general across cultures" (Singh, 2006, p. 784). We can problematize this color/language assignation further by pointing out that many people relate blue to calmness and serenity, where red is the color of wrong answers, check marks, frustration, in-debt, out-of-compliance on many special education online individual education program platforms, and anger. These perceptions are supported by research in management and marketing that link blue to relaxation and happiness and red to sadness (Singh, 2006).

These patterns of directional and font style metonymy are consistent in the data collection across the research sites that included 10 schools with bilingual programs and 100 pictures in these schoolscapes. Findings demonstrate how this pattern of implicitly privileging English over other languages in bilingual schoolscapes is ubiquitous. Below we describe the study, analyze the findings, and call for a translanguaging pedagogy that "confronts colonial language practices with subaltern ones in a border space" (García \& Wei, 2014, p. 41).

\section{Methodology}

\section{Study Setting}

With this study we report on a selection of data collected from 10 public schools (eight primary and two secondary) that celebrate their bilingual programs, including one-way dual language $(N=5)$, two-way dual language $(N=4)$, and 
multilingual newcomers academy $(N=1)$. These schools are all part of the same large, public school district located in the north of the U.S. state of Texas. The three largest racial/ethnic categories of the nearly 90,000 students in the school district are $62 \%$ Hispanic, 31\% Black, 6\% White (Table 1 below in the Findings sections displays the racial/ethnic breakdown by school). The 10 schools selected represent the three kinds of bilingual education offered in the school district and are a representative cross-section of the geographical, cultural, and socioeconomic diversity of the large school district.

\section{Data Collection}

In order to analyze the immediate metonymic impact of the hidden curriculum of monolingualism and English hegemony in these schools, we decided to visually document (through photographs) the first 10 bilingual signs ${ }^{1}$ that an individual would see upon entering the schools. Since most of the signs in these bilingual schools were solely in English, this approach at some schools took the researchers half-way down the main hallway, and in other schools, the 10 bilingual signs were more readily presented and thus documented within the entrance and around the main office. Consistently, the spaces where the signs were found were spaces for providing important information. For example, most of the signs were intended to offer a welcome, provide an important notice or schedule of some kind, and organize certain important learning resources by language (e.g., books in the library).

\section{Methodological-Theoretical Lens}

The Semiotic Index of Gains in Nature \& Society (SIGNS) framework (Przymus \& Kohler, 2018) takes its theoretical basis from multiple lenses of inquiry. At its core, SIGNS is a social semiotic (Van Leeuwen, 2005) framework to be used for linguistic landscape (Shohamy \& Gorter, 2009), along with schoolscape (Brown, 2012) studies. This approach is heavily influenced by Ledin's and Machin's (2020) work on multimodal critical discourse analysis, Kress's and Van Leeuwen's (1996) seminal work on "Reading Images," and Barthes's (1967) extensive work on myth. Although we provide brief practical findings from each of the above theoretical points of analysis in the final section of this paper, the primary focus of this study is on the impact of conceptual metonymy, which has been heavily influenced by the work on multimodal metonymic and metaphoric analysis by Catalano and Waugh $(2013,2014)$.

\section{Findings \& Analysis}

In line with the few schoolscapes studies analyzing language choice in bilingual education settings (Przymus, 2017; Przymus \& Kohler, 2018; Cormier, 2019), here, too, we find the hegemony of English strengthened on the walls of school hallways. Table 1 reveals that $96 / 100$ signs analyzed (96\%) privileged English via directional metonymy; 77/100 (77\%) gave English more value and prominence via font style metonymy; and 69/100 (69\%) contained both metonymies. 
Table 1

Sites of Data Collection: Ten Schools with Bilingual Programs

\begin{tabular}{|c|c|c|c|c|}
\hline School & $\begin{array}{l}\text { Directional } \\
\text { Metonymy } \\
\text { Privileging English } \\
\text { (English on top, or } \\
\text { posted first-on the } \\
\text { left) }\end{array}$ & $\begin{array}{l}\text { Font Style Metonymy } \\
\text { Privileging English } \\
\text { (English-blue, } \\
\text { Spanish-red; English } \\
\text { bigger, bolder, } \\
\text { unmarked, or } \\
\text { Spanish in } \\
\text { parenthesis, not fully } \\
\text { represented, } \\
\text { italicized, etc.) }\end{array}$ & $\begin{array}{l}\text { Signs } \\
\text { Representing } \\
\text { Both } \\
\text { Metonymies }\end{array}$ & $\begin{array}{l}\text { School } \\
\text { Racial/Ethnic } \\
\text { Demographics } \\
\text { (highest three } \\
\text { categories by } \\
\text { percentage) }\end{array}$ \\
\hline $\begin{array}{l}\text { School \#1: Two-way } \\
\text { dual language } \\
\text { (2WDLI) }^{2} \\
\text { classrooms in each } \\
\text { grade (K-5) }\end{array}$ & $\begin{array}{l}9 / 10 \text { (1 Spanish } \\
\text { language sign } \\
\text { was placed to the } \\
\text { left of an English } \\
\text { sign) }\end{array}$ & $7 / 10$ & 5 & $\begin{array}{l}\text { 52\% Hispanic } \\
\text { 34\% White } \\
9 \% \text { Black }\end{array}$ \\
\hline $\begin{array}{l}\text { School \#2: One-way } \\
\text { dual language } \\
\text { enrichment } \\
(1 \mathrm{WDLE})^{3}\end{array}$ & $7 / 10$ & $7 / 10$ & 6 & $\begin{array}{l}85 \% \text { Hispanic } \\
8 \% \text { Black } \\
6 \% \text { White }\end{array}$ \\
\hline $\begin{array}{l}\text { School \#3: } \\
\text { (1WDLE) }\end{array}$ & $10 / 10$ & $9 / 10$ & 7 & $\begin{array}{l}\text { 89\% Hispanic } \\
6 \% \text { Asian } \\
3 \% \text { White }\end{array}$ \\
\hline $\begin{array}{l}\text { School \#4: } \\
\text { (1WDLE) }\end{array}$ & $10 / 10$ & $9 / 10$ & 8 & $\begin{array}{l}35 \% \text { Black } \\
31 \% \text { Asian } \\
23 \% \text { Hispanic }\end{array}$ \\
\hline $\begin{array}{l}\text { School \#5: } \\
\text { (1WDLE) }\end{array}$ & $10 / 10$ & $9 / 10$ & 9 & $\begin{array}{l}\text { 77\% Hispanic } \\
19 \% \text { White } \\
2 \% \text { Black }\end{array}$ \\
\hline $\begin{array}{l}\text { School \#6: } \\
\text { (1WDLE) }\end{array}$ & $10 / 10$ & $10 / 10$ & 10 & $\begin{array}{l}61 \% \text { Black } \\
33 \% \text { Hispanic } \\
3 \% \text { White }\end{array}$ \\
\hline School \#7: (2WDLI) & $10 / 10$ & $8 / 10$ & 8 & $\begin{array}{l}46 \% \text { Black } \\
45 \% \text { Hispanic } \\
7 \% \text { White }\end{array}$ \\
\hline School \#8: (2WDLI) & $10 / 10$ & $7 / 10$ & 6 & $\begin{array}{l}\text { 49\% White } \\
46 \% \text { Hispanic } \\
\text { 4\% Black }\end{array}$ \\
\hline School \#9: (2WDLI) & $10 / 10$ & $6 / 10$ & 5 & $\begin{array}{l}88 \% \text { Hispanic } \\
7 \% \text { White } \\
4 \% \text { Black }\end{array}$ \\
\hline $\begin{array}{l}\text { School \#10: } \\
\text { (newcomers } \\
\text { academy }^{4} \text { ) }\end{array}$ & $10 / 10$ & $5 / 10$ & 5 & $\begin{array}{l}54 \% \text { Hispanic } \\
29 \% \text { Black } \\
12 \% \text { White }\end{array}$ \\
\hline Totals: & $96 / 100$ (96\%) & 77/100 (77\%) & $(69 \%)$ & \\
\hline
\end{tabular}




\section{Examples of Directional Metonymy}

Almost all of the 100 signs (the first 10 seen upon entering each of the 10 schools) demonstrated directional metonymy by placing English first, on the left, and/or on top of the Spanish-language signs. Images 4, 5, and 6, below, are examples from Schools \#4, \#5, and \#7, respectfully.

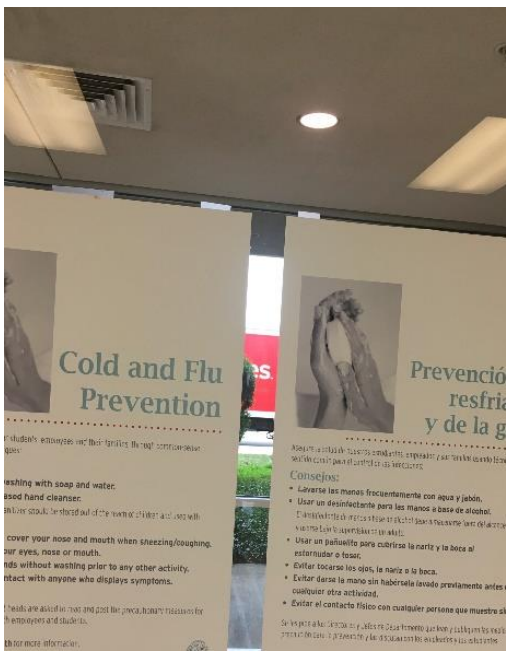

Image 4. Bilingual Signs School \#4

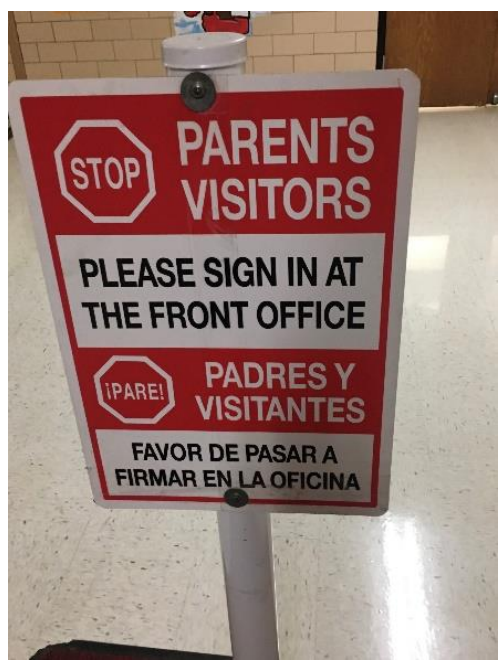

Image 5. Bilingual Sign School \#5

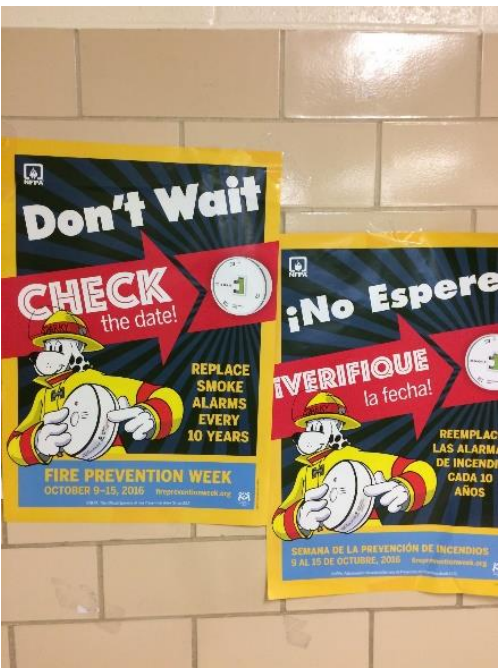

Image 6.

Bilingual Signs School \#7

Images 4 and 5 are typical of this kind of directional metonymy, with English first, on the left, and English on top of the Spanish content. Image 6 strongly demonstrates this directional metonymy by both listing English on the left and on top. What we point out here with directional metonymy is that these signs contain both visual (image) and linguistic (words) information that create what Kress \& van Leeuwen (1996) call representational meaning, interactional meaning, and compositional meaning. In the case of directional metonymy, this implicit meaning and hidden curriculum of ENGLISH IS BEST, MOST IMPORTANT is metonymically produced through the visual syntax (Kress \& van Leeuwen, 1996; Ledin \& Machin, 2020) of "framing" or separating elements in the image, placing English signs or English within signs in places of greater "information value" (i.e., first or on top), and making English stand out with greater "salience" (Ledin \& Machin, 2020). This last concept of drawing readers' attention to English through greater salience is largely accomplished through font style metonymy.

\section{Examples of Font Style Metonymy}

Although not quite as ubiquitous as the directional metonymy, the majority $(77 \%)$ of bilingual signs in these schools had some kind of font style metonymy. 
Images 7, 8, and 9, below, are some of the examples of font style metonymy from Schools \#6, \#8, and \#9, respectfully.

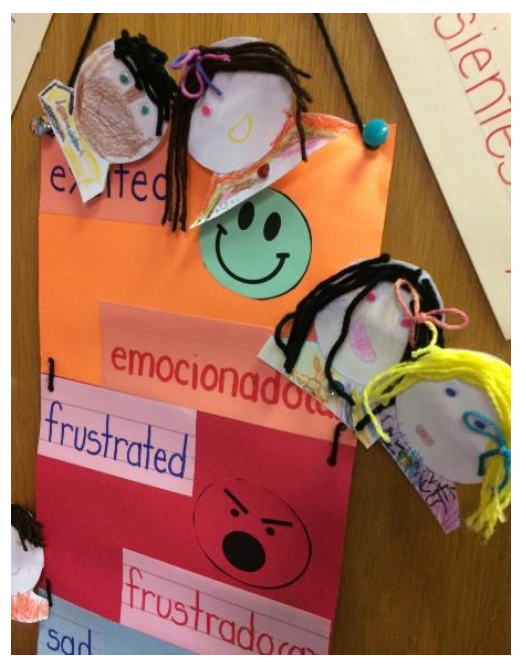

Image 7. Bilingual Signs School \#6

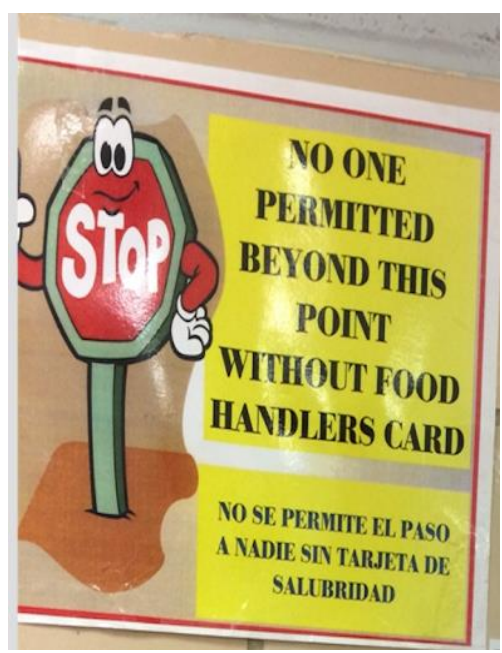

Image 8. Bilingual Sign School \#8

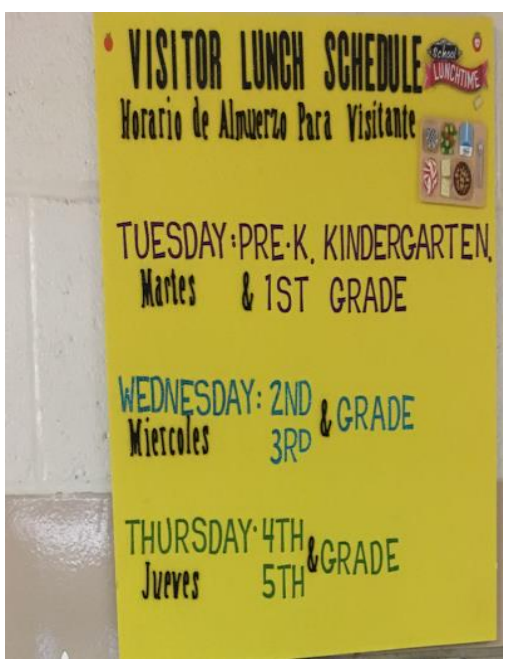

Image 9.

Bilingual Sign School \#9

Image 7 demonstrates font style metonymy by putting English in blue and Spanish in red. The problematization of this color attribution is made even more explicit with the frustrated (mad looking) face being red. Although this image contains a sad face for blue, Ledin and Machin (2020) and Kress and van Leeuwen (2005) have written about the value and the semiotics of colors and state that blue is often associated with purity, truth, science, and knowledge. Image 8 has much smaller font for the Spanish content, and in Image 9, the English content is in block, capitalized letters and the Spanish content is in smaller, upper, and lower-case letters, implicitly creating font style metonymy of ENGLISH IS MOST VALUED through the greater salience of English (Ledin \& Machin, 2020). All three images also demonstrate directional metonymy, with English either on top or listed first, or both as in Image 7 . Both metonymies are represented in $69 \%$ of all of the signs analyzed, such as in Image 10, below, found in the library of School \#3. 


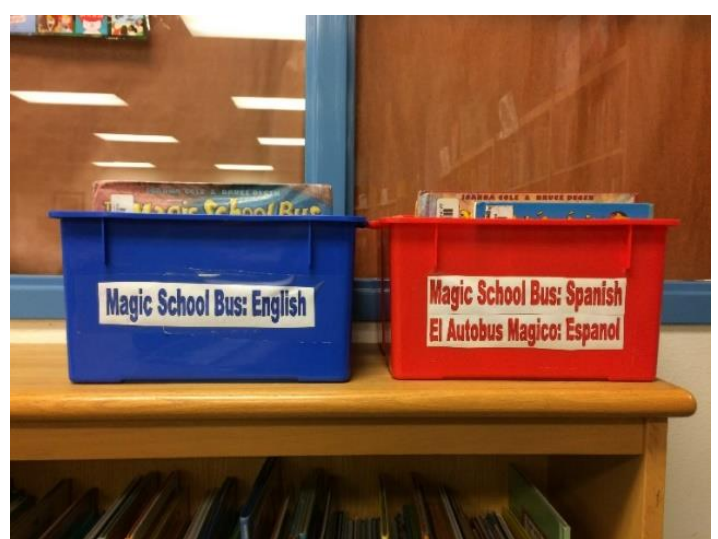

Image 10. Bilingual Signs Separating Magic School Bus Books by Named Language

Image 10 reinforces the directional metonymy by placing the English crate/sign first, on the left, and by labeling the Spanish crate with English first, on top of the Spanish label. These signs reinforce the font style metonymy by, again, problematically separating the languages by color.

\section{A Heteroglossic Way Forward}

The nature of metonymic monolingualism is bi-directional. The monolingual paradigm causes educators to privilege English, even in bilingual schoolscapes and, in return, the existance of the metonymy of monolingualism in bilingual schoolscapes daily reinforces the monolingual paradigm. Languages should not appear separate, as a social act, but rather as a conglomerate resource for meaning making. In questioning the language boundaries and borders as social constructs, we can begin to address the diglossia in bilingual education and work towards contexts of heteroglossia. Bailey (2007) convincingly argues that the perspective of heteroglossia "explicitly bridges the linguistic and the sociohistorical, enriching analysis of human interaction" (p. 269).

There is little evidence of this kind of heteroglossia in these schools. Across the 100 signs analyzed, only Image 11 below challenges the metonymic hegemony of English, and whether it was a conscious decision or not, there seems to be a certain play with languages present in this amalgam of signs. 


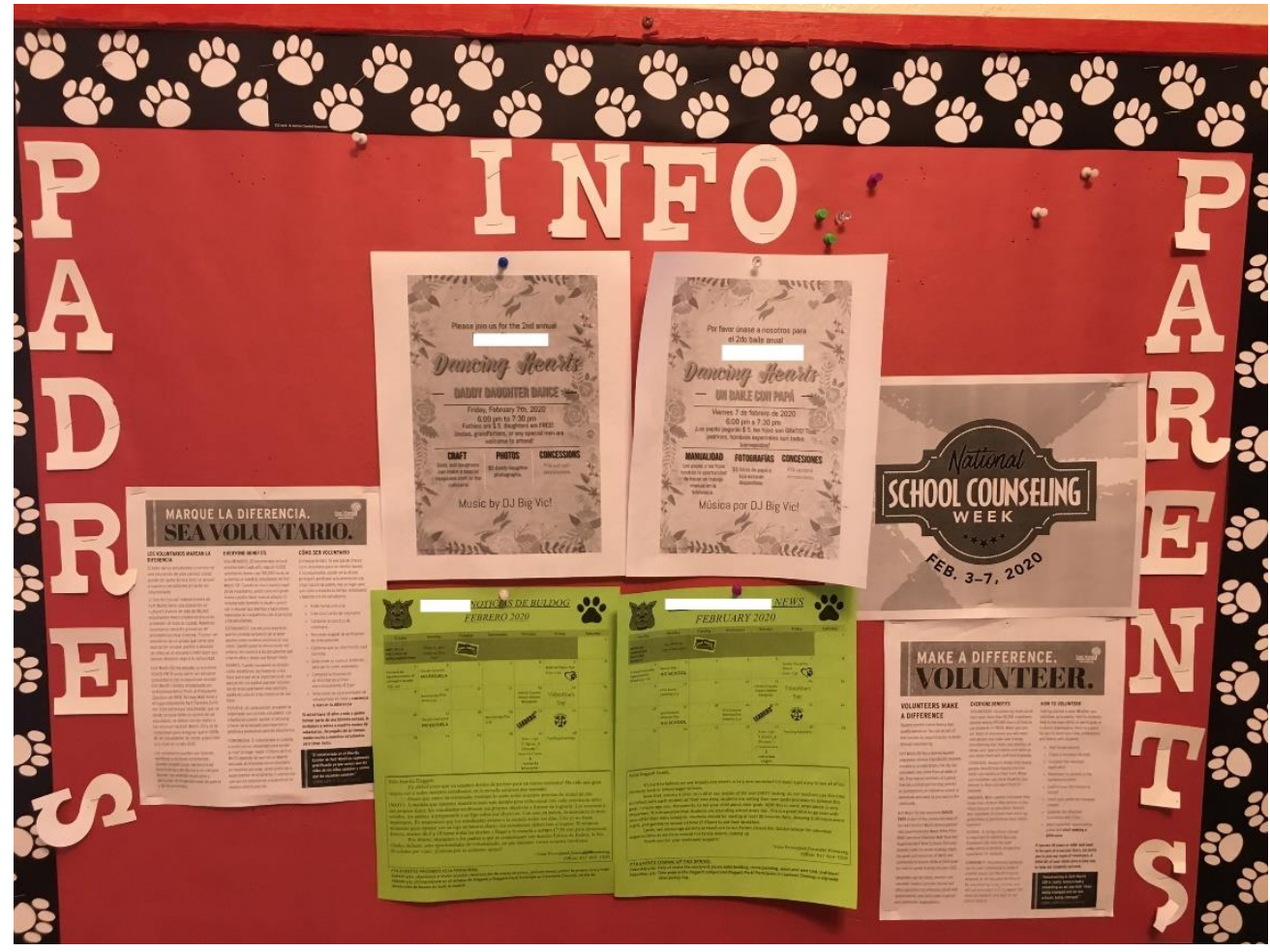

Image 11. Bilingual Bulletin Board in School \#2

Regarding directional metonymy, the Spanish word "PADRES" is listed first, on the left side of the board, with the English "PARENTS" on the right side. The word "INFO," in the middle and on top, could be interpreted as either the abbreviation of the Spanish word "información" or the English word "information." The school dance flyer is listed first on the left in English and second on the right in Spanish, but the volunteer form is listed first, on the left in Spanish and second on the right and a little lower in English. The green calendar is listed first in Spanish and second in English. Regarding font style metonymy, all of the colors are consistent across named languages, all of the fonts are the same size, and both languages are consistently presented with either all caps or a combination of upper and lower-case letters, leaving no language marked nor unmarked. The only reification of English hegemony present is the decision to only post the Englishlanguage sign about "School Counseling Week." Although more heteroglossic in nature, this bulletin board still separates named languages and sends the implicit and incorrect message that bilingualism is really just two monolingualisms present at the same time. How might teachers work with students to co-create signs with translanguaging, or the combination of linguistic features from multiple named languages (Otheguy et al., 2015), in order to more accurately display bilingualism in schoolscapes?

\section{Using SIGNS for LL, Bilingual, and Multicultural Education Studies}

We believe that the SIGNS framework, already applied to LL research (Przymus \& Kohler, 2018), could be used more broadly in other bilingual, multicultural education, and critical race media literacy (CRML) studies that aim to 
work with students to examine problematic representations of race/ism and people of color (Yosso, 2002). Although this current paper focusses on conceptual metonymy (SIGNS's analysis point \#5), we also conducted a diachronic analysis (SIGNS's point \#1) by interviewing current university students who attended one of the 10 analyzed schools as children. All university student interviews and their perspectives shared below adhered to the ethical standards outlined in the authors' Institutional Review Board protocol. Blanca5, a current student in Author 1's Foundations of Language Acquisition course, shared

As I was growing up, I noticed many times how a language I spoke was treated as an "other" and as unimportant via colors and signs. For a long time, I was convinced that the schools I attended also had good reason to do it...After a while, I began to internalize these "hidden" values and believed that it was absolutely my duty to hide my heritage and this other language I spoke because mine was not normal and unimportant.

Via these interviews, we also carried-out a synchronic analysis (SIGNS's point \#2) and learned about current perspectives, such as from one of our doctoral students, who is also an assistant principal in a local school. Jennifer offered that, "this hit very close to home and caused deep reflection on my personal educational practices and practices of my school and district. I see these decisions on a daily basis and have even participated, shamefully, in perpetuating these metonymies."

In class with these students, we discuss the myths (SIGNS's point \#3) and the conceptual metaphors (SIGNS's point \#4) produced and strengthened in these schoolscapes. The first level signification of the myth is that, by using both languages, the languages are equal. The second level signification, however, supports the dominance of English as the language of power, success, and loyalty to nation, creating the conceptual metaphors of ENGLISH IS PATRIOTISM, ENGLISH IS NATIONALISM, and ENGLISH IS AMERICAN (Przymus \& Kohler, 2018).

The syntagmatic axis (SIGNS's point \#6) and the paradigmatic axis (SIGNS's point \#7) are used to teach students how individuals cognitively understand/accept (and therefor do not question) signage organization as a combination of linguistic features (like a sentence) on the syntagmatic axis and through the choice, selection, and alternation of signs on the paradigmatic axis. Finally, via discussions of reverse indexicality (SIGNS's point \#8), students question the significance of educators' elective decisions to organize schoolscapes in a way the reifies the hegemony of English and the circumstantial acceptance of the organization by culturally and linguistically diverse students.

\section{Conclusion}

Life, and most certainly language, is filled with and formed by metonymy that goes unquestioned. Metonymy, and the metaphors based on metonymy, are cognitive mechanisms that "activate neural networks that reinforce semantic domains; that is to say, they spark emotions of good/bad, right/wrong" (Santa Ana 
et al., 2019, p. 27). These emotions inform unconscious decisions of linguistic organization, privileging the monolingual paradigm, and strengthening the hegemony of English. We are products of our linguistic landscape and the agency of things (Bennett, 2010); and, in turn, as Royster (2003) posits below, we become producers, reifying and convincing others of the value of this naturalized order.

In order to make sense of what is before us, we select, focus, and fine-tune the view that we are perceiving or imagining, and we assign to those perceptions value and meaning. We are limited by the choices we make and by the mechanisms and processes we use in shaping them into something that we care about and can persuade others to care about as well. (Royster, 2003, p. 148)

In advocating for equity in education, the meaningful messages of the hidden curriculum of monolingualism that drive ideologies and thus practice, must be questioned. In this paper we have called for, first, the greater awareness of this implicit effect and, second, a response that challenges sociohistorical meanings of signs and forges new schoolscapes that represent and act for shared linguistic and cultural capital. This will not come easy, as it requires self-reflection of perceived good intentions and a willingness to work within the tensions of assumed knowledge and practice. Do educators even have agency over the classroom and school hallways? This agency is certainly not absolute but, at best, temporary and needs constant reflection and (re)evaluation. Midalia (1999) claims that visual images "are never innocent or neutral reflections of reality...they re-present for us: that is, they offer not a mirror of the world but an interpretation of it" (p. 131). In questioning the agency of things and viewing semiotic assemblages in bilingual education contexts as an entenglement of reality, we can better understand the "interactions between people, artefacts and space" (Pennycook, 2017, p. 277) and work towards re-creating and re-presenting a multiculural educational world that is more supportive of the identities and possibilities of culturally and linguistically diverse youth.

\section{Notes}

1. For this study, we considered bilingual signs to be signs that contained both Spanish and English or two signs of the same content, one in Spanish and one in English.

2. Two-way dual language immersion (2WDLI) is a program in which Spanishspeaking and English-speaking students (approximately an equal number of each group) learn grade-level content together in both named languages (usually separated by day or content), with the goals of biliteracy and increased multicultural competence.

3. One-way dual language enrichment (1WDLE) is a program in which all students come from the same linguistic background (e.g., all Spanishspeaking students) and learn grade-level content in both named languages (e.g., Spanish \& English), organized by day/content, and has more of a focus on transitioning students to all English instruction by the end of primary school. 
4. A $6^{\text {th }}-9^{\text {th }}$ grade newcomers' academy, providing $100 \%$ ESL services for students from 25 different countries and who speak/represent 27 different languages.

5. All names are pseudonyms.

\section{References}

Alim, H. S. (2016). Introducing raciolinguistics. In J. R. Rickford, H. S. Alim, \& A. F. Ball (Eds.), Raciolinguistics: How language shapes our ideas about race (pp. 1-30). Oxford University Press.

$\mathrm{Au}, \mathrm{W}$. (2014). Rethinking multicultural education: Teaching for racial and cultural justice (2nd ed.). Rethinking Schools, Ltd.

Bailey, B. (2007). Heteroglossia and boundaries. In M. Heller (Eds.) Bilingualism: A social approach (pp. 257-274). Palgrave Macmillan. https://doi.org/10.1057/9780230596047_12

Barthes, R. (1967). Mythologies. Noonday Press. New York.

Bennett, J. (2010). A vitalist stopover on the way to new materialism. In D. Coole \& S. Frost (Eds.), New materialisms (pp. 47-69). Duke University Press.

Blommaert, J. (2013). Ethnography, superdiversity and linguistic landscapes: Chronicles of complexity (Critical Language and Literacy Studies 18). Multilingual Matters.

Brown, K. D. (2012). The linguistic landscape of educational spaces: Language revitalization and schools in southeastern Estonia. In D. Gorter, H. F. Marten, \& L. V. Mensel (Eds.), Minority languages in the linguistic landscape (pp. 281-298). Palgrave Macmillan. https://doi.org/10.1057 /9780230360235_16

Catalano, T. \& Waugh, L. (2014). The ideologies behind newspaper crime reports of Latinos and Wall Street/CEOs: a critical analysis of metonymy in text and image. Critical Discourse Studies, 10(4), 406-426. https://doi.org/ 10.1080/17405904.2013.813774

Cormier, G. (2019). Translanguaging and linguistic landscapes: A study of Manitoban schoolscapes. OLBI Journal, 10. https://doi.org/10.18192 /olbiwp.v10i0.3236

Creese, A., \& Blackledge, A. (2010). Translanguaging in the bilingual classroom: A pedagogy for learning and teaching?. The Modern Language Journal, 94(1), 103-115. https://doi.org/10.1111/j.1540-4781.2009.00986.x

Garcia, O. (2007). Intervening discourses, representations and conceptualizations of language. In S. Makoni \& A. Pennycook (Eds.), Disinventing and reconstituting languages. Multilingual Matters Ltd., xi-xv. 
García, O., \& Wei, L. (2014). Translanguaging and education. In Translanguaging: Language, bilingualism and education (pp. 119-135). Palgrave Pivot. https://doi.org/10.1057/9781137385765_5

Gibbs, R. W., \& Gibbs, J. (1994). The poetics of mind: Figurative look on the bright side (consistent idiom) thought, language, and understanding. Cambridge University Press.

Gomez, L., Freeman, D., \& Freeman, Y. (2005). Dual language education: A promising 50-50 model. Bilingual Research Journal, 29(1), 145-164. https://doi.org/10.1080/15235882.2005.10162828

Gravelle, M. (1996). Supporting bilingual learners in schools. Stylus Publishing, LLC.

Grosjean, F. (1989). Neurolinguists, beware! The bilingual is not two monolinguals in one person. Brain and language, 36(1), 3-15. https://doi.org/10.1016/0093-934x(89)90048-5

Heller, M. (1999). Linguistic minorities and modernity: A sociolinguistic ethnography. Longman Publishing Group.

Hymes, D. (1992). Inequality in Language: Taking for Granted. Working papers in educational linguistics, 8(1), 1-30. Retrieved from https://files.eric.ed.gov/fulltext/ED354717.pdf

Kontra, M., Phillipson, R., Skutnabb-Kangas, T., \& Varady, T. (1999). Conceptualising and implementing linguistic human rights. In M. Kontra (Ed.), Language, a right and a resource: Approaching linguistic human rights (pp. 1-21). Central European University Press.

Kress, G. R., \& Van Leeuwen, T. (1996). Reading images: The grammar of visual design. Psychology Press.

Landry, R., \& Bourhis, R. Y. (1997). Linguistic landscape and ethnolinguistic vitality: An empirical study. Journal of Language and Social Psychology, 16(1), 23-49. https://doi.org/10.1177/0261927x970161002

Ledin, P., \& Machin, D. (2020). Introduction to multimodal analysis. Bloomsbury Publishing.

Martin, J. R. (1976). What should we do with a hidden curriculum when we find one? Curriculum Inquiry, 6(2), 135-151. https://doi.org/10.2307/1179759

Midalia, S. (1999). 'Textualising Gender.' Interpretations, 32(1), 27-32.

Nöth, W. (2008). Semiotic foundations of natural linguistics and diagrammatic iconicity. In K. Willems \& L. D. Cuypere (Eds.), Naturalness and Iconicity in language. John Benjamins Publishing.

Otheguy, R., García, O., \& Reid, W. (2015). Clarifying translanguaging and deconstructing named languages: A perspective from linguistics. Applied Linguistics Review, 6(3), 281-307. https://doi.org/10.1515/applirev-20150014 
Panther, K. U., \& Thornburg, L. (2005). The role of conceptual metonymy in meaning construction. In F. J. Ruiz de Mendoza lbáñez \& M. S. Peña Cervel (Eds.), Cognitive linguistics: Internal dynamics and interdisciplinary interaction (pp. 353-386). Walter de Gruyter GMbH \& Co. KG.

Peirce, C. S. (1998). Kaıva otoıxєıа ('new elements'). In Peirce Edition Project (Eds.), The Essential Peirce, Vol. 2 (1893-1913), 300-324. Indiana University Press (original work published 1904).

Pennycook, A. (2010). Critical and alternative directions in applied linguistics. Australian review of applied linguistics, 33(2), 16.1-16.16. https://doi.org/10.2104/aral1016

Pennycook, A. (2017). Translanguaging and semiotic assemblages. International Journal of Multilingualism, 14(3), 269-282. https://doi.org/ 10.1080/14790718.2017.1315810

Phillipson, R. (1992). Linguistic Imperialism. Oxford University Press.

Przymus, S. D. (2016). Challenging the monolingual paradigm in secondary duallanguage instruction: Reducing language-as-problem with the 2-1-L2 model. Bilingual Research Journal, 39(3-4), 279-295. https://doi.org/10.1080/15235882.2016.1220995

Przymus, S. D. (2017). The subliminal influence of street signs in schoolscapes: Elective vs. circumstantial reverse indexicality in a tale of two Tucsons. Journal of Second Language Acquisition and Teaching, 24, 4-24. Retrieved from https://journals.uair.arizona.edu/index.php/AZSLAT/article/view /21355/20929

Przymus, S. D., \& Kohler, A. T. (2018). SIGNS: Uncovering the mechanisms by which messages in the linguistic landscape influence language/race ideologies and educational opportunities. Linguistics and Education, 44, 5868. https://doi.org/10.1016/j.linged.2017.10.002

Royster, J. J. (2003). Disciplinary landscaping, or contemporary challenges in the history of rhetoric. Philosophy \& Rhetoric, 36(2), 148-167. https://doi.org/10.1353/par.2003.0022

Santa Ana, O., Juárez, M. A., Reséndez, M., Hernández, J., Gaytan, O., Cerón, K., Gómez, C. and Hirose, Y. (2019). Documenting the President's Verbal Animus against Immigrants to defend DACA grantees. Final Report of DACA Defense Team. University of California Los Angeles. Retrieved from https://issuu.com/ottosa/docs/19_final_report_0115.docx

Shohamy, E., \& Gorter, D. (2009). Linguistic landscape: Expanding the scenery. Routledge.

Singh, S. (2006). Impact of color on marketing. Management decision.

Swain, M. (1983). Bilingualism without tears. In M. A. Clarke \& J. Handscombe (Eds.), On TESOL '82: Pacific Perspectives on Language Learning and Teaching (pp. 35-46). Teachers of English to Speakers of Other 
Languages. Retreived from https://files.eric.ed.gov/fulltext/ ED228890.pdf\#page $=42$

Van Leeuwen, T. (2005). Introducing social semiotics. Psychology Press.

Wang, Y. (2020). Conveying the shadow: A positive hidden curriculum in women's doctoral experiences with the nomadic subjects theory [Unpublished doctoral dissertation]. Texas Christian University.

Waugh, L. R. (1994). Degrees of iconicity in the lexicon. Journal of pragmatics, 22(1), 55-70. https://doi.org/10.1016/0378-2166(94)90056-6

Yosso, T. J. (2002). Critical race media literacy: Challenging deficit discourse about Chicanas/os. Journal of Popular Film and Television, 30(1), 52-62. https://doi.org/10.1080/01956050209605559

\section{Author Contact}

Steve Przymus s.przymus@tcu.edu

College of Education, TCU Box 297900, Fort Worth, Texas 76129

Gabriel Huddleston, g.huddleston@tcu.edu

College of Education, TCU Box 297900, Fort Worth, Texas 76129 